\title{
Water use efficiency as a measure to assess forest carbon uptake for different management strategies
}

Linderson, Maj-Lena; Mikkelsen, Teis Nørgaard; Ibrom, Andreas; Lindroth, A.; Pilegaard, Kim

Publication date:

2009

Link back to DTU Orbit

Citation (APA):

Linderson, M-L., Mikkelsen, T. N., Ibrom, A., Lindroth, A., \& Pilegaard, K. (2009). Water use efficiency as a measure to assess forest carbon uptake for different management strategies. Poster session presented at IARU International Scientific Congress: Climate Change: Global Risks, Challenges and Decisions, Copenhagen, Denmark.

\section{General rights}

Copyright and moral rights for the publications made accessible in the public portal are retained by the authors and/or other copyright owners and it is a condition of accessing publications that users recognise and abide by the legal requirements associated with these rights.

- Users may download and print one copy of any publication from the public portal for the purpose of private study or research.

- You may not further distribute the material or use it for any profit-making activity or commercial gain

- You may freely distribute the URL identifying the publication in the public portal 


\section{WATER USE EFFICIENCY AS A MEASURE TO ASSESS FOREST CARBON UPTAKE FOR DIFFERENT MANAGEMENT STRATEGIES}

1. Introduction. New tools are needed to assess carbon uptake for different forest management strategies and species composition where other methods, e.g. flux towers, fail due to large spatial integration. Water use efficiency (WUE) - the relationship between carbon uptake $\left(\mathrm{F}_{\mathrm{c}}\right)$ and water use of the tree $\left(\mathrm{F}_{\mathrm{w}}\right)$ - is considered to be a conservative species property only depending on the vapour pressure deficit (VPD):

$\frac{F_{c}}{F_{w}} V P D=$ constant

The aim of this study is to assess the possibility to use water use efficiency (WUE) as a means for up scaling leaf carbon uptake to forest stand scale. If the relationships hold, carbon uptake may be calculated from sap flow measurements.

2. Data. $F_{c}$ and $F_{w}$ were measured at four different heights during the growing seasons of 1999 and 2000 in a Danish 80-years old beech (Fagus sylvatica L) forest, using an LCA-3 infrared gas analyser (ADC) with a Parkinson leaf chamber.

The MAESTRA model was parameterised according to physiological observations of the Soroe beech forest (e.g. leaf optical properties, vertical leaf area distribution and tree structure) and used to up scale leaf WUE to canopy WUE.

3. Method. The leaf physiology observations were used to evaluate leaf WUE variability and its environmental dependencies (fig. 1). The following equation was fitted:

$$
\frac{F_{c}}{F_{w}} V P D=0.35+6.98(1-\exp (-0.0051 P A R))
$$

Whole tree carbon half-hourly and daily uptake was assessed by applying the observed leaf WUE*VPD equation to the MAESTRA model simulations, thus using the meteorological and physiological effects on the light distribution within the canopy to assess the canopy WUE.

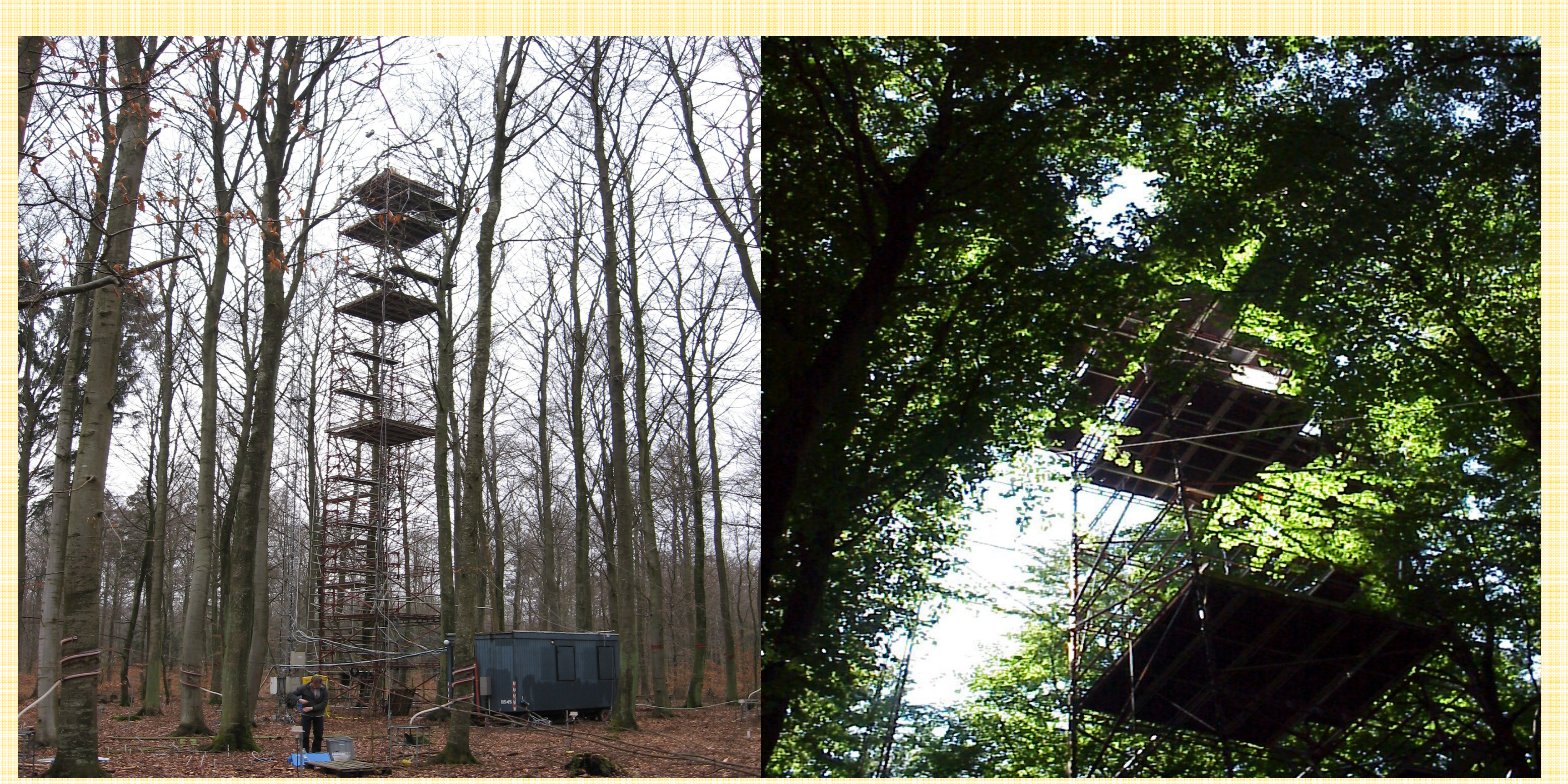

Figure 1. Scaffold tower with the four height levels (24, 22, 18 and $12 \mathrm{~m}$ ). During summer the lower levels are fairly dark.

Acknowledgement. This work was funded by a FP 6 Marie Curie Intra-European Fellowship.

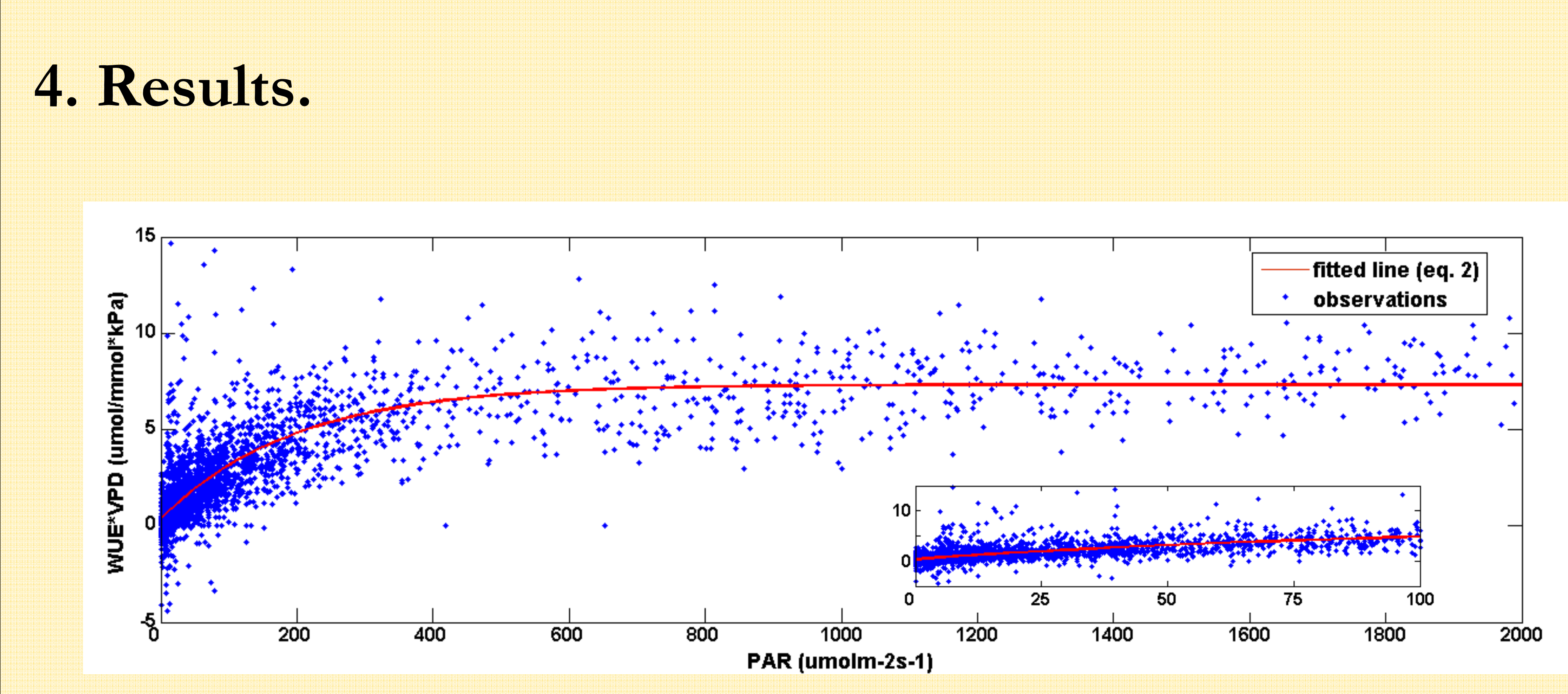

Figure 2. WUE*VPD as a function of PAR using 2900 leaf physiology measurements. The residuals of the function (eq. 2) are independent of both different levels of the trees and of the variation in environmental parameters.
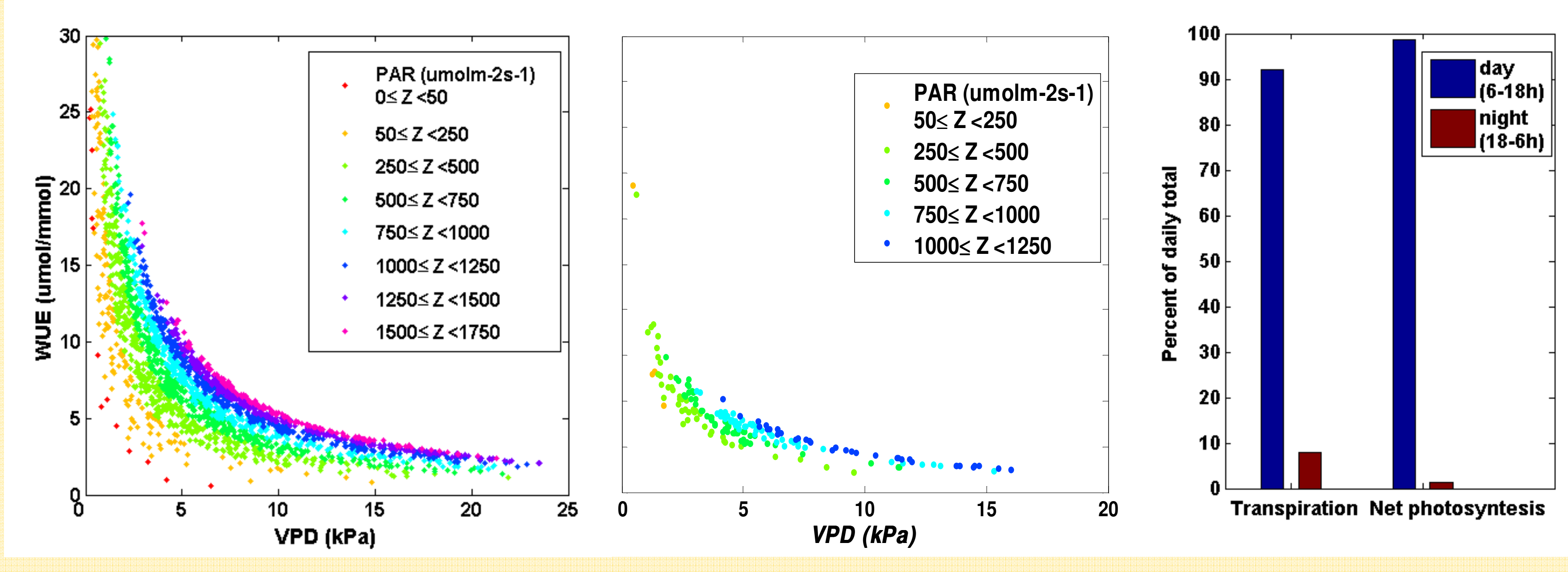

Figure 3. Model simulations. Left and middle plots show the dependency of canopy WUE on VPD for half-hourly averages (left) and for daily averages (middle). Estimations are made from 15 May to 15 August at daytime (6-18 hours). Right panel shows the simulated daily total canopy transpiration and net carbon uptake at daytime (6-18 hours) and outside these hours.

5. Conclusions. Canopy net carbon uptake can successfully be calculated from sap flow measurements for the Soroe beech forest based on the following findings:

- Observations show that WUE is dependent of incoming PAR below $250 \mu \mathrm{mol} \mathrm{m}^{-2} \mathrm{~s}^{-1}$ and, for the full range, dependent on VPD and independent of both different levels of the trees and for the variation in environmental parameters.

-Modelled daily canopy WUE for daytime fluxes (6-18 hours) are dependent only on VDP and light and may thus be assessed from sap flow in combination with PAR and VPD measurements above the forest.

-Low morning and evening fluxes are not included in the estimations but constitute only to a small part of the fluxes and are thus negligible.

The method, so far, require that woody respiration and night time leaf respiration is treated separately.

\section{References.}

Ibrom, A. et al., 2006. A comparative analysis of simulated and observed photosynthetic CO2 uptake in two coniferous forest canopies. Tree Physiology, 26(7): 845 - 864 . Pilegaard, K. et al., 2003. Field measurements of atmospherebiosphere interactions in a Danish beech forest. Boreal

Bierbuizen, I. F. and Slatyer, R. O., 1965. Effect of atmospheric concentration of water vapour fluxes over terrestrial ecosystems. Global Change Biology 2: 159-168.

(chocchi, D. D., Verma, S. B. and Anderson, D. E., 1987. Canopy photosynthesis and water-use efficiency in a deciduous forest. Journalof Applied Ecology 24: 251_260. 